\title{
Determinants of technology transfer in Vietnam: An empirical analysis
}

\author{
Hoai Nam Nguyen a and Quoc Hoi Le ${ }^{b^{*}}$
}

${ }^{a}$ Faculty of Economics, Vinh University, Vietnam

${ }^{b}$ Faculty of Economics, National Economics University, Vietnam

\section{H R O N I C L E}

Article history:

Received: December 18, 2019

Received in revised format: Janu-

ary 29,2020

Accepted: February 9, 2020

Available online: February 9, 2020

Keywords:

Determinant

Technology transfer

International trade

Vietnam

\section{A B S T R A C T}

This paper examines the determinants of technology transfer through international trade in Vietnam by using provincial level data. The paper investigates the similarities and differences between the adoption of technology from OECD and non-OECD countries. The empirical finding shows that the skills of labor force and openness to trade are the most robust determinants of technology adoption at the provincial level. Furthermore, provinces with higher levels of R\&D expenditure adopt more technology from OECD countries than do other provinces.

O) 2020 by the authors; licensee Growing Science, Canada.

\section{Introduction}

Technology transfer and international trade are widely recognized as important factors for economic development (Jovanovic, 1998; Wooldridge, 2002). Much evidence related to cross-country economic performance suggests that the rate of economic growth of a country depends on the extent of adoption and implementation of new technology. De Long and Summers (1993) provide an empirical evidence to show the strong effects of equipment investment on economic growth in both developed and developing countries. Lee (1995) confirms that the rate of machinery imports from OECD countries has a significant positive effect on per capita income growth rate in developing countries. Coe and Helpman (1995), and Coe et al. (1997) find that international technological spill overs are closely related to machinery and equipment imports. However, there has not much evidence, which is known empirically on the determinants of technology adoption. Caselli and Coleman (2001) have examined the determinants of computer adoption in the last thirty years. However, the problem with this analysis is that they do not provide us with the big picture. Because they consider specific technologies, it is hard to distinguish technology 
specific anecdotes from general adoption patterns. Therefore, it is worthwhile to distill out the adoption and diffusion processes that most major technologies seem to have in common as economic theory often tends to aim for explaining general facts rather than specific anecdotes (Barro \& Sala-i-Martin, 1995; Gilchrist \& Williams, 2004).

This paper examines the determinants of technology transfer in a cross section of 55 provinces in Vietnam from 1996 to 2016. In addition, the similarities and differences between the adoption of technology transfer from OECD countries and non-OECD countries to Vietnam are investigated. The main results show that openness to international trade and educational level of labor force play a key role in the adoption of new technologies. The paper is organized as follows. Section 2 reviews the theoretical framework on determinants of technology transfer. The empirical model is presented in section 3. Section 4 provides empirical results and discussion. Section 5 is conclusion.

\section{Theoretical Framework on Determinants of Technology Transfer}

\subsection{Concepts of Technology and Technology Transfer}

According to the dictionary of economics of Babock (1989, p.398), technology is defined as "the sum of knowledge of the means and methods of producing goods and services". Technology is thus relevant to specific goods or service and comprises all knowledge embodied in physical assets and workers that allow an efficient organisation and production of those goods or services within a particular environment. Technology covers widely different components. In a narrow definition, technology includes the knowledge embodied in machinery, equipment and intermediate goods used in the production process at any given time. As Groizard (2002) has argued, one advantage of this definition is that although the production of capital goods is highly concentrated in developed countries, the imports of capital goods and intermediate goods emerge as a reasonable proxy for technology transfer. In addition, Xu and Wang (1999) state that trade in capital goods is more relevant than total trade for measuring technology diffusion because capital goods have higher technological content than consumption goods. Technology transfer is an investment resource process for updating and upgrading the quality of capital good installed. Technology is often transferred from developed countries to developing countries. Developed countries account for the largest world capital and intermediate goods production and relative R\&D expenditures. As a result, developed countries will export technological products and developing countries in turn will import these goods (Pham \& Hoang, 2019).

\subsection{Determinants of Technology Transfer}

\subsubsection{Human capital}

The level of human capital plays important roles in facilitating technology adoption. First, human capital determines the capacity of a country to carry out technological innovation (Romer, 1990). Secondly, it is most importantly for a country to adopt and efficiently implement foreign technology. Nelson and Phelps (1966) suggest that the rate at which the gap between the technology frontier and the current level of productivity is closed depend on the level of human capital. Using cross-country data, Bartel and Lichtenberg (1987), Benhabid and Spiegel (1994), and Foster and Rozenzweig (1995) investigate the NelsonPhelps hypothesis and conclude that technology spillovers flow from leaders to followers and the rate of flow depends on levels of education. Consequently, human capital is central in technology transfer. Trained workers largely influence the adoptive capacity of firms, reducing the costs of technological imitation or adoption. Recently, Araújo and Teixeira (2014) explore the key factors that foster technology transfer within the triad university-industry-government in the Enterprise Europe Network (EEN). They find that high levels of formal schooling are not a key determinant of international technology transfer and the critical factor is highly educated human resources who receive complementary training in technology transfer issues. 


\subsubsection{Trade}

There is a great deal of theoretical and empirical literature emphasizing the role of international trade as a determinant of technology diffusion and adoption around the world. Trade may affect the rate of technology adoption in a country through both direct and indirect effects. The direct effect is emphasized in Grossman and Helpman (1991) in the sense that countries, which import goods from countries that are more technologically advanced, get more exposure to new technological developments. As a result, they will be more likely to adopt the technologies that they are exposed to. Besides the direct effect of trade mentioned above, there is the indirect effect. Holmes and Schmitz (2001) consider the case in which domestic producers in a country spend a significant chunk of resources on protecting themselves from their domestic competitors. However, these resources are not successful in the protection against foreign competition. Therefore, when trade barriers are lifted, these domestic producers shift from their protective activities to the more productive innovative activities that are necessary to sustain their international competitiveness (Nguyen et al., 2018; Lucas, 1998; Wolfgang, 2001).

\subsubsection{Domestic R\&D activities}

Technology transfer and R\&D activities share a complementary relationship. R\&D activities not only involve innovation but also learning (Cohen \& Levinthal, 1989). A by-product of R\&D is therefore to enhance a country's or a firm's absorptive capacity, which in turn boosts the efficacy of technology transfer. Kneller et al. (2010) examine how absorptive capacity affects international technology transfer and find that R\&D activities, workforce education and training are pointed out as the main indicators of a firm's absorptive capacity.

\subsubsection{Institution}

Institutions, which include the norm, rules and organizations, may determine the effect of technology adoption. Phan (2019) shows that some institutions like intellectual property rights may facilitate strategically important technology transfer from the parent to the affiliates and may also stimulate innovative activities. Differences in technology adoption across countries may be due to differences in the effectiveness of the legislation and the type of regime in these countries. Tihanyi and Roath (2002) examine the problems associated with technology transfer in the context of Central and Eastern European countries and conclude that different country institutional characteristics are determinants of technology transfer. Specifically, the adoption of essential market institutions and the specific norms of regional integration with the European Union are the most important determinants of technology transfer.

\subsubsection{Factor endowments}

Factor endowments measured as part of conventional factors of production, such as investment, income or infrastructure, may affect the speed of adoption of new technologies for three reasons. First, if technology and a factor of production are complementary, the marginal value of the new technology will be increasing in the level of the factor. Therefore, countries with high endowments of complementary factors will have a chance to adopt technologies first (Javanovic, 1998; Hobijn, 2001). Secondly, if technology and the relevant factor are substitutes, firms will have higher incentives to invest in factor saving technologies when the price of the factor is relatively high (Acemoglu, 2001). Finally, if technologies are specific to the combination of inputs, new technologies will only be implemented successfully by countries with appropriate portfolio of endowments (Basu \& Weil, 1998; Gurajati, 2003).

\section{Empirical Model}

The determinants of technology transfer are estimated with a specification of the following form:

$$
F R D_{i t}=\alpha+\beta X_{i t}+v_{t}+\varepsilon_{i t}
$$


where $F R D_{i t}$ is the ratio of machinery and equipment imports from foreign countries to GDP in province $i$ and year $t . X_{i t}$ is macroeconomic and institutional set of explanatory variables explaining the capability of a province to adopt foreign technologies, $v_{t}$ is the Asian financial crisis dummy, and $\varepsilon_{i t}$ is an error term identically and independently distributed across provinces and time. The explanatory variables $(X)$ are classified into seven categories. The classifications of these variables are as follows:

(i) Standard variables, which contain the growth rate of real GDP per capita and the ratio of domestic investment to GDP. We include these variables in order to capture both income and investment effects that inherently contribute to the different rates of technology adoption as well as endowment differences across provinces that are omitted in other variables.

(ii) Human capital endowments are used not only as inputs in production but also fulfill crucial tasks in the creation and adoption of technologies. Human capital is influenced by the level of education, job training and work-experience. In this study, the human capital variables are measured by educational attainment and by the percentage of skilled workers in total labor force. Based on the Vietnamese context, educational attainment is specified as 5 years, 9 years and 12 years for primary school graduates, secondary school graduates and high school graduates respectively.

(iii) Domestic R\&D inputs should be the sum of R\&D inputs of domestic firms, government as well as scientific and research institutes. However, since R\&D inputs of both domestic firms and research institutes are unavailable, and government $R \& D$ expenditures in various levels are the major sources of Vietnam's R\&D inputs for a long period, and government R\&D expenditures are chosen as the index of domestic R\&D.

(iv) Trade variable refers to the level of openness of each province. The level of openness is defined as the ratio of exports plus imports to GDP in each province.

(v) Factor endowment variables that take into account the share of agriculture and the share of industry in GDP. These variables also measure the comparative advantage of each province.

(vi) Infrastructure: Since there exists no comprehensive indicator of infrastructure, an individual aspect of infrastructure is used. In this study, we use the number of telephones per 1,000 people in a province to proxy for its infrastructure.

(vii) Fixed effect variables which will necessarily impact the model. Obviously, economic business cycles, the Asian financial crisis from 1996 to 1998 and the global financial crisis from 2007 to 2008 in this case, are likely to impact results. Therefore, an Asian financial crisis dummy and a global financial crisis are included in all of the specifications.

Three types of econometric estimation for the cross-sectional time-series data, simple pooled OLS, fixed effects (FE) model and random effects (RE) model, are considered in this study. The advantage of pooled OLS is that it has more degrees of freedom, but this method assumes that the intercepts and slope coefficients are the same across provinces and time. The FE model incorporates differences between provinces in the sense that it allows intercepts to vary across different provinces, but assumes the intercepts stay constant over time. The RE model also allows the intercepts to change for different provinces, but the changes are random. The Breusch-Pagan LM test shows that the FE and RE model are preferred to the pooled model. In addition, the Hausman test is used to decide between the fixed effect and the random effect specifications. This test shows that the fixed effect estimate is more efficient than the random effect estimate. Therefore, FE estimation is adopted to examine the panel characteristics of the data set.

\section{Empirical results and discussion}

Eq. (1) is tested for 55 provinces and for the 1996-2016 period when data for all the variables are available. The regression results are introduced in Table 1. Each column represents different specifications of the model. The first and the second ones show the role of different measures of human capital in technology transfer. The results in columns 3 and 4 are the determinants of technology transfer from OECD 
countries and non-OECD countries by decomposing the total sample into OECD sample and non-OECD sample.

Table 1

The determinants of technology transfer in Vietnam (Fixed effects panel data estimate)

Dependent variable: The ratio of capital goods imports to GDP

\begin{tabular}{|c|c|c|c|c|}
\hline Explanatory variable & Total sample & Total sample & OECD & Non-OECD \\
\hline \multirow[t]{2}{*}{ GDP per capita } & 0.05 & 0.06 & 0.01 & 0.03 \\
\hline & $(0.01)^{* * *}$ & $(0.01)^{* * *}$ & $(0.008)^{* *}$ & $(0.01)^{* * *}$ \\
\hline \multirow[t]{2}{*}{ Domestic R\&D } & -0.40 & 0.28 & 1.09 & -1.49 \\
\hline & $(1.72)$ & $(1.72)$ & $(0.84)^{*}$ & $(1.31)$ \\
\hline \multirow[t]{2}{*}{ Skills } & 0.07 & & 0.04 & 0.03 \\
\hline & $(0.02)^{* *}$ & & $(0.01)^{* * *}$ & $(0.02)^{*}$ \\
\hline Schooling & & $\begin{array}{l}-0.03 \\
(0.18)\end{array}$ & & \\
\hline \multirow[t]{2}{*}{ Investment/GDP } & -0.02 & -0.01 & -0.009 & -0.01 \\
\hline & $(0.01)^{* *}$ & $(0.01)^{*}$ & $(0.005)^{*}$ & $(0.008)^{*}$ \\
\hline \multirow[t]{2}{*}{ Openness } & 0.64 & 0.65 & 0.14 & 0.50 \\
\hline & $(0.16)^{* * *}$ & $(0.16)^{* * *}$ & $(0.07)^{*}$ & $(0.12)^{* * *}$ \\
\hline \multirow[t]{2}{*}{ Inflation } & 0.001 & 0.001 & -0.0003 & 0.001 \\
\hline & $(0.006)$ & $(0.006)$ & $(0.003)$ & $(0.004)$ \\
\hline Agricultural share in & -0.04 & -0.03 & -0.02 & -0.02 \\
\hline GDP & $(0.02)^{* *}$ & $(0.02)^{*}$ & $(0.01)^{*}$ & $(0.01)^{*}$ \\
\hline Industry share in & 0.002 & 0.001 & -0.002 & 0.005 \\
\hline GDP & $(0.01)$ & $(0.01)$ & $(0.007)$ & $(0.01)$ \\
\hline \multirow[t]{2}{*}{ Infrastructure } & -0.006 & 0.001 & -0.007 & 0.001 \\
\hline & $(0.003)$ & $(0.003)$ & $(0.001)^{* * *}$ & $(0.002)$ \\
\hline \multirow[t]{2}{*}{ DVFC } & -0.19 & -0.19 & -0.09 & -0.10 \\
\hline & $(0.14)$ & $(0.14)$ & $(0.06)$ & $(0.10)$ \\
\hline \multirow[t]{2}{*}{ DVGC } & -0.15 & -0.14 & -0.11 & -0.11 \\
\hline & $(0.12)$ & $(0.12)$ & $(0.09)$ & $(0.09)$ \\
\hline \multirow[t]{2}{*}{ Constant } & 0.82 & 1.31 & 0.60 & -0.22 \\
\hline & (1.02) & $(1.55)$ & $(0.50)$ & $(0.78)$ \\
\hline Observations & 605 & 605 & 605 & 605 \\
\hline R-squared & 0.54 & 0.53 & 0.51 & 0.43 \\
\hline Hausman Test & $77.51 * * *$ & $61.67 * * *$ & $78.10 * * *$ & $74.24 * * *$ \\
\hline
\end{tabular}

Notes: $* * *$ and $* * *$ indicate statistically significant at the $10 \%, 5 \%$ and $1 \%$ respectively. Standard errors are in parentheses

The results in all regressions show that openness to international trade is one of the most relevant and robust determinants of technology transfer in Vietnam. When trade openness is measured as the ratio of exports and imports to GDP, openness is the highest coefficient and significantly positive at $1 \%$ level. In particular, the results show that a 1\% increase in the ratio of exports and imports to GDP would generate a $0.64 \%$ increase in technology transfer. This suggests that when provinces are open to trade, they are not only buying products from abroad, but they are also establishing information channels that are extremely useful for the transfer of technology. Another robust finding is that the skill of labor force is an important determinant of technology transfer. In all regressions, the coefficients on skills are positive and significant. This implies that skills and elementary knowledge in the labor force are necessary for the acquisition of technological skills and the use of new technologies through learning by doing and learning 
on job techniques. However, when human capital is measured as the educational attainment, the coefficients on this variable are not significant. This is due to the fact that Vietnam has not met a certain threshold level of education to adopt foreign technology. Moreover, the quality of education may matter. Teaching may not be updated to satisfy the requirements of development practice. These can make educational quantification of less practical value.

\section{Table 2}

The determinants of technology transfer in Vietnam (one year lag) (Fixed effects panel data estimate) Dependent variable: The ratio of capital goods imports to GDP

\begin{tabular}{|c|c|c|c|c|}
\hline Explanatory variable & Total sample & $\begin{array}{c}\text { Total } \\
\text { sample }\end{array}$ & OECD & Non-OECD \\
\hline Lagged GDP per capita & $\begin{array}{c}0.01 \\
(0.01)\end{array}$ & $\begin{array}{c}0.02 \\
(0.01)\end{array}$ & $\begin{array}{c}0.004 \\
(0.008)\end{array}$ & $\begin{array}{l}0.008 \\
(0.01)\end{array}$ \\
\hline Lagged domestic R\&D & $\begin{array}{l}-0.32 \\
(1.68)\end{array}$ & $\begin{array}{c}0.40 \\
(1.68)\end{array}$ & $\begin{array}{c}0.61 \\
(0.82)\end{array}$ & $\begin{array}{l}-0.94 \\
(1.28)\end{array}$ \\
\hline Lagged skills & $\begin{array}{c}0.10 \\
(0.03)^{* * *}\end{array}$ & & $\begin{array}{c}0.04 \\
(0.01)^{* *}\end{array}$ & $\begin{array}{c}0.06 \\
(0.02)^{* *}\end{array}$ \\
\hline Lagged schooling & & $\begin{array}{l}-0.25 \\
(0.20)\end{array}$ & & \\
\hline Lagged investment/GDP & -0.01 & -0.006 & -0.002 & -0.01 \\
\hline Lagged openness & $\begin{array}{c}(0.01) \\
0.37\end{array}$ & $\begin{array}{c}(0.01) \\
0.41\end{array}$ & $\begin{array}{c}(0.005) \\
0.05\end{array}$ & $\begin{array}{c}(0.007) \\
0.32\end{array}$ \\
\hline Lagged inflation & $\begin{array}{c}(0.17)^{* *} \\
0.004\end{array}$ & $\begin{array}{c}(0.17)^{* *} \\
0.004\end{array}$ & $\begin{array}{c}(0.04)^{*} \\
0.001\end{array}$ & $\begin{array}{c}(0.13)^{* *} \\
0.003\end{array}$ \\
\hline Lagged agricultural share in & $(0.006)$ & $(0.006)$ & $(0.003)$ & $(0.004)$ \\
\hline GDP & -0.06 & -0.03 & -0.01 & -0.04 \\
\hline Lagged industry share in GDP & $(0.02)^{* *}$ & $(0.02)^{*}$ & $(0.01)$ & $(0.01)^{* *}$ \\
\hline Lagged infrastructure & $\begin{array}{c}-0.004 \\
(0.01)\end{array}$ & $\begin{array}{l}-0.01 \\
(0.01)\end{array}$ & $\begin{array}{l}-0.005 \\
(0.007)\end{array}$ & $\begin{array}{l}0.001 \\
(0.01)\end{array}$ \\
\hline DVFC & $\begin{array}{c}-0.008 \\
(0.005)^{*}\end{array}$ & $\begin{array}{c}0.003 \\
(0.004)\end{array}$ & $\begin{array}{c}-0.009 \\
(0.002)^{* * *}\end{array}$ & $\begin{array}{c}0.001 \\
(0.003)\end{array}$ \\
\hline DVGC & $\begin{array}{l}-0.28 \\
(0.13)\end{array}$ & $\begin{array}{c}-0.30 \\
(0.13)^{*}\end{array}$ & $\begin{array}{c}-0.15 \\
(0.06)^{*}\end{array}$ & $\begin{array}{l}-0.12 \\
(0.10)\end{array}$ \\
\hline Constant & $\begin{array}{l}-0.15 \\
(0.21)\end{array}$ & $\begin{array}{c}-0.16 \\
(0.22)\end{array}$ & $\begin{array}{c}-0.14 \\
(0.12)\end{array}$ & $\begin{array}{l}-0.13 \\
(0.11)\end{array}$ \\
\hline Observations & 1.44 & 3.55 & 0.78 & 0.65 \\
\hline R-squared & $(1.07)$ & $(1.65)^{* *}$ & $(0.52)$ & $(0.82)$ \\
\hline Hausman Test & $\begin{array}{c}605 \\
0.54 \\
39.73 * * *\end{array}$ & $\begin{array}{c}605 \\
0.53 \\
36.79 * * *\end{array}$ & $\begin{array}{c}605 \\
0.51 \\
35.61 * * *\end{array}$ & $\begin{array}{c}605 \\
0.45 \\
37.60 * * *\end{array}$ \\
\hline
\end{tabular}

Notes: $* * *$ and $* * *$ indicate statistically significant at the $10 \%, 5 \%$ and $1 \%$ respectively. Standard errors are in parentheses.

The growth rate of GDP per capita is also an important determinant of technology transfer. Provinces with high growth rate of GDP per capita can adopt more foreign technology. A $1 \%$ increase in GDP per capita leads to a $0.05 \%$ rise in technology transfer in the total sample, $0.03 \%$ from non-OECD countries and $0.01 \%$ from OECD countries. The size of the agriculture sector is a good predictor of technology transfer at the provincial level. In particular, provinces with higher shares of agriculture in GDP import less new technologies than other provinces. $R \& D$ expenditures of a province do not affect its capability to adopt technology from non-OECD countries. However, provinces with higher levels of R\&D expenditures adopt more technology from OECD countries. This may be due to the fact that technology from OECD countries is more complicated than from non-OECD ones. Therefore, the success of adopting technology from OECD countries in each province depends not only on the skills of its labor force, but also on its R\&D expenditures that reflect the absorptive capacity of each province. There appear to be different effects of the level of a province's infrastructure on technology adoption from OECD countries and non-OECD countries. Provinces with lower level of infrastructure import more technology from OECD countries than other provinces. However, technology imports from non-OECD countries are not 
affected by the level of infrastructure. The Asian financial crisis and the global financial crisis do not significantly affect technology imports of each province. Similarly, inflation rate is not a significant influential factor of technology transfer in Vietnam. Surprisingly, investment in a province affects negatively its technology imports. This may imply that technology import is less in more capital-intensive activities. Since technology imports in the past may help increase current GDP, and the current GDP and current investment may be the determinants of technology adoption in the future, identifying the determinants of technology transfer may suffer from endogeneity. Hence, it is necessary to use lagged explanatory variables to reflect the time lap so that the effects from influential factors on technology transfer can take effect. Explanatory variables lagged by one year are chosen. In general, the regression results of the one-year lag models in Table 2 are rather similar to the results shown in Table 1. In particular, these results show that openness to international trade and skills of labour force are important explanatory factors of technology transfer in Vietnam, and they are robust to variation in specifications.

\section{Conclusion}

This paper has examined the determinants of technology transfer via trade from both OECD countries and non-OECD countries in Vietnam. The empirical results based on data across the Vietnamese provinces provide strong evidence that openness to international trade is one of the most relevant and robust determinants of technology transfer at provincial level. Moreover, provinces have to invest in human capital to adopt new technologies. Human capital is crucial in order to transfer foreign technology and to maintain sustainable provincial economic growth. Two important roles of human capital are highlighted in this paper. On the one hand, human capital directly improves output levels by improving the education and skill levels of workers and therefore the productivity of employees. On the other hand, human capital also indirectly promotes economic growth by enhancing the level of the country's absorptive capability and R\&D efficiency. Another finding in this paper is that technology transfer from OECD countries depends not only on the skills of labour force, but also on the R\&D activities in each province.

\section{References}

Acemoglu, D. (2001). Directed Technical Change. NBER Working Paper 8287, National Bureau of Economic Research.

Araújo, C., \& Teixeira, A. (2014). Determinants of international technology transfer: an empirical analysis of the Enterprise Europe Network. Journal of Technology Management \& Innovation, 9(3), 120-134.

Babock, G. (1989). The Dictionary of Economics. $5^{\text {th }}$ ed. Hutchison Business Books, Great Britain.

Barro, R. J., \& Sala-i-Martin, X. (1995). Economic Growth McGraw-Hill. New York.

Bartel, A. P., \& Lichtenberg, F. R. (1987). The comparative advantage of educated workers in implementing new technology. The Review of Economics and statistics, 1-11.

Basu, S. \& Weil, D. (1998). Appropriate Technology and Growth. Quarterly Journal of Economics, 113, 1025-1054. https://doi.org/10.1162/003355398555829

Benhabid, J., \& Speigel, M. (1994). The role of human capital in economic development: Evidence from aggregate cross-country data. Journal of Monetary Economics, 34, 143-173. https://doi.org/10.1016/0304-3932(94)90047-7.

Caselli, F., \& Coleman, W. J. (2001). Cross-country technology diffusion: The case of computers. American Economic Review, 91(2), 328-335.

Coe, D. T., \& Helpman, E. (1995). International r\&d spillovers. European Economic Review, 39(5), 859887.

Coe, D. T., Helpman, E., \& Hoffmaister, A. W. (1997). North-south R \& D spillovers. The Economic Journal, 107(440), 134-149. 
Cohen, W. M., \& Levinthal, D. A. (1989). Innovation and learning: the two faces of R \& D. The economic journal, 99(397), 569-596.

De Long, J.B. \& Summers, L.H. (1991). Equipment investment and economic growth. Quarterly Journal of Economics, 106, 445-502. https://doi.org/10.2307/2937944.

Foster, A. D., \& Rosenzweig, M. R. (1995). Learning by doing and learning from others: Human capital and technical change in agriculture. Journal of Political Economy, 103(6), 1176-1209.

Gilchrist, S., \& Williams, J. C. (2004). Transition dynamics in vintage capital models: explaining the postwar catch-up of Germany and Japan (No. w10732). National Bureau of Economic Research.

Groizard, J. (2002). On the determinants of the international embodied technology diffusion. University of the Balearic Island.

Grossman, G., \& Helpman, E. (1991). Innovation and growth in the global economy. MIT press, Cambridge, Massachusetts.

Gurajati, D. (2003). Basic econometrics. McGraw-Hill

Hobijn, B. (2001). Is equipment price deflation a statistical artifact? FRBNY Staff Report 139, Federal Reserve Bank of New York.

Holmes, T. \& Schmitz, J. (2001). A gain from trade: From unproductive to productive entrepreneurship. Journal of Monetary Economics, 47, 417-446. https://doi.org/10.1016/S0304-3932(01)00044-7.

Jovanovic, B. (1998). Vintage capital and Inequality. Review of Economic Dynamics, 1, 497-530. https://doi.org/10.1006/redy.1998.0013.

Kneller, R., Pantea, S., \& Upward, R. (2010, August). Does Absorptive capacity affect who benefits from international technology transfer. In Twelfth Annual Conference.

Nguyen, T.M., Le, Q.H., Tran, T.V.H., \& Nguyen, M.N (2018), Ownership, technology gap and technical efficiency of small and medium manufacturing firms in Vietnam: A stochastic meta frontier approach. Decision Science Letters, 8(3), 225-232. https://doi.org/10.5267/j.dsl.2019.3.002

Tihanyi, L \& Roath, A. (2002). Technology transfer and institutional development in Central and Eastern Europe. Journal of World Business, 37, 188-198. https://doi.org/10.1016/S1090-9516(02)00077-9

Lichtenberg, F. \& van Pottelsberghe de la Potterie (1998). International R\&D spillovers: A comment. European Economic Review, 42, 1483-1491. https://doi.org/10.1016/S0014-2921(97)00089-5.

Lucas, R. (1998). On the mechanics of economic development. Journal of Monetary Economics, 22, 342. https://doi.org/10.1016/0304-3932(88)90168-7.

Nelson, R., \& Edmund, P., (1966). Investment in humans, technological diffusion, and economic growth. American Economic Review, 56, 69-75.

Phan, T.T.A., (2019). Does organizational innovation always lead to better performance? A study of firms in Vietnam. Journal of Economics and Development, 21(1), 71-82.

Pham, T.L., \& Hoang, H.V. (2019). The relationship between organizational learning capability and business performance: The case of Vietnam firms. Journal of Economics and Development, 21(2), 259-269. https://doi.org/10.1108/JED-10-2019-0041.

Romer, P. (1990). Endogenous technological change. Journal of Political Economy, 98, s71-S102.

Wolfgang, K., (2001). International technology diffusion. NBER Working Paper no. 8573.

Wooldridge, J (2002). Econometric analysis of cross section and panel data. The MIT press, Cambridge, Massachusetts.

Xu, B. \& Wang, J. (1999). Capital goods trade and R\&D spillovers in the OECD. Canadian Journal of Economics, 32, 1258-1274. https://doi.org/10.2307/136481. 


\section{Appendix}

List of Variables of Determinants of Technology Transfer

\begin{tabular}{|c|c|c|}
\hline Name of variables & Specification of variables & Source of data \\
\hline \multicolumn{3}{|l|}{ Dependent variable } \\
\hline$F R D_{i t}$ & $\begin{array}{l}\text { The ratio of machinery and equipment imports } \\
\text { in province } i \text { in year } t \text { to its GDP in the corre- } \\
\text { sponding year. }\end{array}$ & $\begin{array}{c}\text { Vietnam's General Statis- } \\
\text { tics Office } \\
(\mathrm{GSO}) \\
\end{array}$ \\
\hline \multicolumn{3}{|l|}{ Independent variables } \\
\hline$G D P_{i t}$ & $\begin{array}{l}\text { The growth rate of real GDP per capita in } \\
\text { province } i \text { in year } t \text {. }\end{array}$ & GSO \\
\hline Investment / $G D P_{i t}$ & $\begin{array}{l}\text { The ratio of investment to GDP in province } \mathrm{i} \\
\text { in year } \mathrm{t} \text {. }\end{array}$ & GSO \\
\hline Openness $_{i t}$ & $\begin{array}{l}\text { The ratio of imports and exports to GDP in } \\
\text { province } i \text { in year } t \text {. }\end{array}$ & GSO \\
\hline Agricultural share $_{i t}$ & $\begin{array}{l}\text { The share of agricultural sector in GDP in } \\
\text { province } i \text { in year } t \text {. }\end{array}$ & GSO \\
\hline Industry share $_{i t}$ & $\begin{array}{l}\text { The share of industrial sector in GDP in prov- } \\
\text { ince } i \text { in year } t \text {. }\end{array}$ & GSO \\
\hline Schooling $_{i t}$ & $\begin{array}{l}\text { The educational attainment in province } \mathrm{i} \text { in } \\
\text { year } \mathrm{t} \text {. }\end{array}$ & $\begin{array}{l}\text { Ministry of Labor, Invalids } \\
\text { and Social Affairs of Vi- } \\
\text { etnam } \\
\text { (MoLISA) }\end{array}$ \\
\hline Skills $_{i t}$ & $\begin{array}{l}\text { The percentage of skilled workers in the total } \\
\text { labour force of province } i \text { in year } t \text {. }\end{array}$ & MoLISA \\
\hline Inflation $_{i t}$ & The rate of inflation in province $\mathrm{i}$ in year $\mathrm{t}$. & GSO \\
\hline$D R D_{i t}$ & $\begin{array}{l}\text { The ratio of } R \& D \text { expenditures to GDP in } \\
\text { province } i \text { in year } t \text {. }\end{array}$ & $\begin{array}{l}\text { Ministry of Science, Tech- } \\
\text { nology and Environment of } \\
\text { Vietnam } \\
\text { (MoSTE) }\end{array}$ \\
\hline & $\begin{array}{l}\text { The number of telephone machines per } 1000 \\
\text { people in province } i \text { in year } t \text {. }\end{array}$ & MoSTE \\
\hline$D V F C$ & $\begin{array}{l}\text { Dummy variable for the Asian financial cri- } \\
\text { sis. One for the year } 1997 \text { to } 1999 \text { and zero for } \\
\text { the others. }\end{array}$ & \\
\hline$D V G C$ & $\begin{array}{l}\text { Dummy variable for the global financial cri- } \\
\text { sis. One for the year } 2007 \text { and } 2008 \text { and zero } \\
\text { for the others. }\end{array}$ & \\
\hline
\end{tabular}


(C) 2020 by the authors; licensee Growing Science, Canada. This is an open access article distributed under the terms and conditions of the Creative Commons Attribution (CC-BY) license (http://creativecommons.org/licenses/by/4.0/). 